Volume 8, No.5, September - October 2019

International Journal of Advanced Trends in Computer Science and Engineering

Available Online at http://www.warse.org/IJATCSE/static/pdf/file/ijatcse70852019.pdf

https://doi.org/10.30534/ijatcse/2019/70852019

\title{
Best Practices of Technology Business Incubators in the Philippines
}

\author{
Jennifer P. Alinsunod ${ }^{1}$, Francisco D. Esponilla $\mathrm{II}^{2}$, Hasmin T. Ignacio ${ }^{3}$, Heronafine C. de Guzman ${ }^{4}$, \\ Kevien C. Dela $\mathrm{Cruz}^{5}$, Ira C. Valenzuela ${ }^{6}$ \\ ${ }^{1}$ Technological University of the Philippines, jennifer_alinsunod@tup.edu.ph \\ ${ }^{2}$ Technological University of the Philippines, francisco_esponilla@ tup.edu.ph \\ ${ }^{3}$ Technological University of the Philippines, hasmin_ignacio@tup.edu.ph \\ ${ }^{4}$ Technological University of the Philippines, heronafine_deguzman@tup.edu.ph \\ ${ }^{5}$ Technological University of the Philippines, kevien_cabarrubias @ tup.edu.ph \\ ${ }^{6}$ Technological University of the Philippines, ira_valenzuela@ tup.edu.ph
}

\begin{abstract}
Technology business incubator (TBI) is one of drive factors that uplift the economic status of a country. It is normally supported by the government to stimulate firms and commercialize technologies developed by the universities. While the Philippines has recently began the establishment of TBIs, challenges have been experienced. These challenges were overcome through trial and error method while adapting to the economic responses. This study presents the best practices of Philippines TBIs. Seven (7) TBIs were randomly selected all over the country. Structured survey and interview questionnaire were used for the gathering of the data. The outcomes of the practices were validated through actual site observation. A framework indicating the success metric for TBIs was developed which consists of (1) driving mechanism and (2) process of implementations.
\end{abstract}

Key words : TBIs, best practice, start ups, small businesses, technology.

\section{INTRODUCTION}

A growing interest in Technology Business Incubators (TBIs) has been rapidly observed in the recent years. This interest is clearly manifested in a continuous campaign on technology innovation and entrepreneurship through establishments of TBIs in the Philippines and around the globe which further opens its gateway to alleviate the global problem, i.e. poverty for developing countries, and advance economic growth for developed countries.

TBI is seen as the "variant of more traditional business incubation schemes, assist technology-oriented entrepreneurs in the start-up and early development stage of their firms by providing workspace (on preferential and flexible terms), shared facilities, and a range of business support services" [1]. On the other hand, [2] stated that the general aim of TBI is to help startup companies to be independent by providing various services such as training, use of office space, and other business-related services. According to [3], TBI's goals can be both or either about (1) developing economic status of a country by lessening unemployment rate, and/or (2) stimulating firms or by commercializing technologies produced by the universities or research centers.

In the Philippines, three (3) government agencies have been working together to create and assist startup companies. These agencies are Department of Science and Technology (DOST), Department of Information and Communications Technology (DICT), and the Department of Trade and Industry (DTI) that came up with the four strategies, i.e. collaboration, policy, promotion, and education [4] to promote technology entrepreneurship. The Commission on Higher Education has also granted various universities financial assistance for the establishment of incubation centers. Based on the 2017 Philippine Surveys, there were more than 20 incubation centers, 30 investors, and 20 venture capitalists [5], and over 300 startups where 200 of them were active as of July 2018 [6]. Of 20 incubation centers, there were 14 centers funded by the DOST, some were established in partnership with other agencies.

Around the world, there have been thousands of incubation centers operating for several years, and they have been encountering challenges brought by many factors such as lack of criteria for evaluating business incubators, inadequate guidelines for the implementation of programs, and insufficient data or case studies on other countries[7], inadequate financial resources, hiring qualified employees, lack of partnering opportunities, no mindset for entrepreneurship [8]. These challenges were just a few of the problems that lead to the formulation of this present study. The purpose of the study is to identify the best practices of TBIs in the Philippines. 


\section{RELATED WORKS}

Despite challenges encountered, many TBIs are still active and operational knowing that $90 \%$ of the startups fail, and the majority of TBIs are also startups too [9]. These challenges push management to find ways to sustain and maintain them. The study of [10] shed light on how to identify the best practices of TBIs in developed and developing countries. Based on their study, best practices can be determined through the incubators' outcomes, such as economic advancement, innovation, and entrepreneurship. Through the use of multi-case studies and review of literature studies, it has found out that all case studies obtained from the six (6) TBIs of the United States, Europe, and in Asia underscore the value of (1) facilities or equipment, (2) finances, (3) advisory services, (4)mentoring/coaching, (5) incubation services, (6) international business services, (7) networks and synergy, (8) technology transfer, (9) commercializing technology as best practices that can incubator shall ensure [10].

Singharam and et. al mentioned in their article the seven components that determine the success of an incubator. These are infrastructure, employment generation, no. of incubates companies, successful exits, funding raised, the sustainability of the incubator, and network and engagement. Singharam concluded that the success of an incubator cannot be based on one parameter but having none or two parameters do not mean TBIs are unsuccessful. Measuring the effectiveness of TBIs, based on their study, can be seen if their startups grow faster than the average [9].

In United Kingdom, best practices at an operational level, according to the Centre for Strategy and Evaluation Services (CSES), can be determined through (1) ensuring that the incubators' operations are integrated in the regional technology development strategies and partnerships, (1) target clients/ markets shall be defined as well as the adopting admission criteria,(2) emphasizing on the training for the incubators, and use of virtual incubation services [11].

Reference [11] conducted a study on the best practices on the global good practice in incubation policy development and implementation through the review of related literature and four case studies in Brazil, Malaysia, New Zealand, and South Africa. In the study, it was recommended that the following should be key identified: (1) Consistency between objectives and the broader strategic framework, (2) Consistency between objectives pursued and suitable service mix, (3) Stakeholder support, (4) Investing in Pre-incubation, (5) Address gaps in the Business Environment, (6) Commercial approach, (7) Ensuring elements of competition and merit in grants assignments, (8) Financial sustainability, (9) Networking and Public-Private Partnerships, (10) Monitoring and Appraisal, and (11) hiring effective Incubator Manager.
On the other hand, eight selected incubation centers in Europe were the subjects of [12] study in which relevant challenges and considerations relative to best practices are asked. Key dimensions such as facilities and equipment, financing opportunities, partnerships and networking, business knowledge, and incubator's internal management were the focus of Custer's study. In his report, it was found out that it is best likely to consider (1) facilities and equipment in order to get a direct access to the development and testing of new prototypes, (2) financing opportunities to further develop the incubators skills or obtain financial support from different organizations, (3) partnership and networking to promote collaborations between research centers and entrepreneurs, (4) business knowledge to support incubators on their incubation programmes and strategies, and (5) incubator's internal management to cluster incubator manager's knowledge and increase understanding of how to connect and maintain such relationships.

The paper will present the TBI profiles including the TBI focus, and its clients. Another section of this paper will discuss the identified best practices provided by the TBI managers, and the formulated success metrics of the TBIs in a developing country like the Philippines.

\section{METHODOLOGY}

The researchers randomly chose seven (7) TBIs in the Philippines. These TBIs were selected based on the recommendation of the other visited TBIs. Another criterion is that TBIs should be operational in not less than two years. The structured survey and interview questionnaire are the main instruments of the study. The data were collected using the in-situ assessment where in the researchers visited the TBI's sites and conducted a survey and interview with the TBI's officials. The outcomes of the practices were validated through actual site observation on the facilities and equipment, organizational structure, financing opportunities, partnership and linkages, and entrepreneurial mindset.

The data collected were subjected to an in-depth analysis which utilizes the standard coding process in order to come up with an integrated classification of clustered responses [13-17].

\subsection{Profile of TBIs}

Table 1 shows the profile of the selected TBIs in the Philippines. As can be seen, there were seven (7) TBIs participated in this study. TBI 1 is currently catering engineering/IT student- researchers who are specializing Information and Communication Technology, Electronics System and Engineering Design and Development. In addition, the TBI is promoting its services through pitching competitions, seminars, and workshops. Lastly, the center is 
in the process of honing the potentials of the entrepreneurial ecosystem among faculty members, staff, students, alumni, community and other stakeholders.

Aside from training, coaching, and mentoring the incubatees, TBI 2 is responsive to the needs of the community by specializing in agriculture and food products and processes. It is for this reason that the local industry, local government, and small-scale business entrepreneurs took part in the incubation project. Currently, the TBI is in the process of looking for national and international patronage of their agricultural products. In fact, they are in the production of dried jackfruit ready for patronage by the local and the national market but packaging for possible business collaboration with the international market.

TBI 3, on the other hand, focuses on Manufacturing/ Recycling Creative Industry in the Visayas to help micro-, small-, and medium-scale enterprises (MSMEs) and the community maximize their resources and their full potential as entrepreneurs.

In the Visayas, there are two TBIs that have been part of this study. TBI 4 focuses on Artificial Intelligence, Engineering, Robotics, Data Analytics, Green Technology, and Food innovations while TBI 5 caters academic community with their technological inventions.

TBI 6 is shared facilities funded by Regional DOST. It is targeted to help Agriculture and Food products of the region.
Its target clients are the regional community and academic community.

TBI 7 is another shared facilities funded by the Regional DOST that targets Technology and Engineering. Its target clients are the Academic Community of the University, Its alumni, and its regional community.

\section{RESULTS AND DISCUSSION}

This section discusses the results and discussion of the collected data from the various TBIs in the Philippines.

Table 2 presents the best practices of seven TBIs. As shown, TBI 1 manager enumerated their best practices, i.e. strong partnership and linkages in various funding government funding agencies, non- government organizations, and other local and international funding institutions, conducive environment with state-of-the-art facilities for incubates, equipped trainers, use of space and facilities, established framework for the implementation of programs, aligned programs and activities, IP implementation, financial resources, and continuous training. For some TBIs, the main purpose of establishing TBI in a university is to support that small-scaled entrepreneur of a particular community [18] and venture. Thus, it has the advantage of ensuring funding from become partners of economic development [19]. TBI 3 has the advantage of its people. The in situ assessment conducted by

Table 1: Profile of TBIs

\begin{tabular}{|c|c|c|c|}
\hline TBIs & TBI Focus & Clients & Location \\
\hline TBI 1 & $\begin{array}{l}\text { ICT, Electronics System } \\
\text { Food Processing, Engineering }\end{array}$ & Students and alumni and potential entrepreneurs. & Luzon \\
\hline TB1 2 & Agriculture and Food & $\begin{array}{l}\text { Industries, } \\
\text { Local Government, } \\
\text { Small-scale business entrepreneurs }\end{array}$ & Visayas \\
\hline TBI 3 & $\begin{array}{l}\text { Manufacturing/ Recycling } \\
\text { Creative Industry } \\
\text { (Creating innovative products that are not } \\
\text { sold outside the Province) }\end{array}$ & $\begin{array}{l}\text { hundreds of micro-, small-, and medium-scale } \\
\text { enterprises (MSMEs), and the community }\end{array}$ & Visayas \\
\hline TBI 4 & $\begin{array}{l}\text { Artificial Intelligence, Engineering, } \\
\text { Robotics, Data Analytics, Green } \\
\text { Technology, and Food }\end{array}$ & Academic community & Visayas \\
\hline TBI 5 & Technological innovations & Tech based enterprises & Visayas \\
\hline TBI 6 & Agriculture and Food & $\begin{array}{l}\text { regional community, alumni and academic } \\
\text { community }\end{array}$ & Mindanao \\
\hline TBI 7 & Technology and Engineering & $\begin{array}{l}\text { regional community, alumni and academic } \\
\text { community }\end{array}$ & Mindanao \\
\hline
\end{tabular}


the researchers, the university it was found out that for only period of 2 years, the employees in the university are cooperative and supportive of TBIs activities. Management and employee's engagement is an indicator of a successful supporting agencies like DOST, the local government, and community entrepreneurs. As an agricultural university, foods and other agribusiness products and services are catered to where the clients took patronage too. The takers of the TBIs products and services are the local community, the local government unit, and nearby businessindustries in the region 8. Other products are sold in the university business center where employees and students bought for their consumption. Since the business center is just beside the national highway, passers-by also buy their products to take home and giveaways. One of the requirements for running an incubation center is having the facilities readily available to cater to the needs of the incubate [20]. In TBI 3 (pertains to VSU), likewise with other TBI, it is a common practice that a shared working facility is present. This served as space for a collaborative working avenue by and between the incubators and incubatees.

TBI 4 manager believes that through strong networks and collaborations with various government and non-government organizations, the incubation center will live long and able to sustain its operations. In fact, the facilities and equipment of TBI 4 were donated and funded by the government and other organizations which serve as the income-generating mechanism of the center. The manager was trained and tasked to conduct benchmarking on various TBIs in Asia as sponsored by the government and other funding agencies. The benchmarking activities, according to TBI 4 manager, build partnership and linkages among TBIs and industries making the center known to Asia. Other best practices were (1) involving the management (university) in the activities in the center, (2) continuous conduct of mentoring and coaching to the startup partners, and (3) continuous conduct of training, seminars, and other relevant classes for the community assisting them to do their own business.

TBI 5 is fully supported by the university. The university recognizes its importance of having TBI in an institution. The university has exclusively assigned the entire 3rd floor of the main building for the TBI to house the TBI activities, start-ups, meeting rooms, display room, and office use. The DOST has provided financial support to the university given that the TBI location has already been set up for the conduct of the TBI business. With available equipment and materials for use, processing of products on engineering technology, information technology, and robotics are made according to the needs of the start-up. The said TBI products were the research results from the selected students who won in their annual research exhibit [24]. TBI 5 provides basic infrastructures, machines that are branded financed by the
Department of Science and Technology (DOST) and a collaborative workspace to share ideas for design, coding, prototyping and the like. TBI 5 also provides assistance concerning registration of intellectual property.

TBI 6 sets out precise criteria for the selection of incubators before starting each incubation project; and details of the incubation program and the support activities of the incubatees. The selection process cannot guarantee a hundred percent success rate; however, careful selection of potential candidates will increase the likelihood of successful candidates, which directly affects the success of the business incubator [21]. The selection process of the prospective candidate irrefutably determines the success of the incubator [22]. TBI 5 provides basic infrastructures, training, coaching and mentoring to the incubatees-business operation, accounting, finance product/service research, and development.

TBI 7 is supported by the administrators and funded by the Region's Department of Science and Technology. The University has state of the art food laboratory and has its design packaging equipment. TBI's 7 food products are winning awards. They have well-defined vision, mission, strategies, objectives, and goals.

TBI 8 is supported and funded by the administrator by the Region's Department of Science and Technology. TBI 8 focuses on technology and engineering research. TBI 8 needs a lot of space for heavy equipment; and to solve this problem, TBI 8 is currently building their new center.

Figure 1 shows the success metrics of TBIs in the Philippines which were classified into two domains such as the driving mechanism and process of implementation. The formulated metrics were obtained from the collected data of the best practices of TBIs in the Philippines. As shown in the figure, the driving mechanism refers to the potentials, resources, strategies, and forces of TBIs and the process of implementation which is referred to the practices, actions, and strategies for the establishment and sustainability of the TBIs.

Under the domain of driving mechanism are the parameters such as partnership and linkages with government and non-government funding institution, conducive environment with state of the art facilities, qualified trainers, financial support to the start-up/ incubates, institutional and management support and engagement and provision for the establishment of TBIs. Similar to the various studies, parameters such as partnership and linkages, space, facilities and equipment play important roles in operating TBIs [10-12]. 
Table 2: Best Practices of Selected TBIs in the Philippines

\begin{tabular}{|c|c|}
\hline TBIs & Best Practices \\
\hline $\begin{array}{l}\text { TB1 } \\
1\end{array}$ & $\begin{array}{l}\text { Strong partnership and linkages in various funding government funding agencies, non- government organizations, and } \\
\text { other local and international funding institutions. } \\
\text { The center has a conducive environment with state-of-the-art facilities for incubatees. } \\
\text { Trainers are well trained in their respective fields of specialization. } \\
\text { The center has its own framework in promoting their services } \\
\text { The programs and activities of the Center are aligned on the Vision, Mission, and Goals of the University } \\
\text { Other students, alumni, and community members are allowed to utilize the facilities of the Center. } \\
\text { Provide start-ups with financial resources and continuous coaching and mentoring } \\
\text { Strong in implementation of intellectual property rights }\end{array}$ \\
\hline TBI 2 & $\begin{array}{l}\text { Strong TBI Support from both the university management and the rank and file faculty and staff } \\
\text { Available funding from various government agencies, local government, and local industry. } \\
\text { Presence of a TBI center for the marketing of goods, products, and services. } \\
\text { Available working, training, and warehouse facilities. } \\
\text { Know-how in coaching and mentoring of incubatee to survive the small business enterprise. } \\
\text { Provisions to secure administrative and statutory requirements. } \\
\text { Enough location sites for TBI product processing and manufacturing. } \\
\text { Existing of TBI building and various research centers in the university. }\end{array}$ \\
\hline TBI 3 & $\begin{array}{l}\text { Strong network, linkages, and partnership with different funding agencies, non-government organizations, local and } \\
\text { international incubation centers } \\
\text { Continuous benchmarking for best practices } \\
\text { Involve the management in the activities of the center } \\
\text { Alignment of programs and activities of the center with its goals, vision, and missions } \\
\text { Continuous conduct of mentoring and coaching among startups } \\
\text { Continuous conduct of training, seminars, and other relevant classes for the community } \\
\text { Allow the community to utilize facilities and equipment as part of income-generating mechanism }\end{array}$ \\
\hline TBI 4 & $\begin{array}{l}\text { Ensuring the support of the university in terms of providing space and facilities, and activities of the center } \\
\text { Mentoring students to use their research as startups } \\
\text { Well-defined vision, mission, strategies, objectives and goal } \\
\text { Access to technology for the production and processing of incubatees' products and/or services. } \\
\text { Access to specialized equipment, laboratories, and research facilities. } \\
\text { Help build incubate relationships with higher education institutions and facilitate the use of institutions ' facilities, } \\
\text { equipment, and laboratories. } \\
\text { Support of intellectual property registration. }\end{array}$ \\
\hline TBI 5 & $\begin{array}{l}\text { Well-defined vision, mission, strategies, objectives and goal. } \\
\text { Precise criteria for the selection of incubatees before commencing each incubation project. } \\
\text { TBI supporting services before and after incubation and offer various training/coaching/mentoring for startups } \\
\text { support and promotion for incubates from both the public and private sectors. } \\
\text { Create a networking environment for incubatees with other entrepreneurs and businesses within and outside the business } \\
\text { community. }\end{array}$ \\
\hline TBI 6 & $\begin{array}{l}\text { Well-defined vision, mission, strategies, objectives, and goal. } \\
\text { Complete Food Laboratory, facilities and Equipment from processing to packaging. } \\
\text { Funded by Local Department of Science and Technology } \\
\text { Support from the Administrator and Department of Science and Technology }\end{array}$ \\
\hline TBI 7 & $\begin{array}{l}\text { Well-defined vision, mission, strategies, objectives and goal. } \\
\text { Facilities, Equipment and building is supported by the school administrator and Department of Science and Technology } \\
\text { Funded by the Local Department of Science and Technology } \\
\text { Support from the Administrator and Department of Science and Technology }\end{array}$ \\
\hline
\end{tabular}


On the other hand, stakeholder's support from the academic community and government will strengthen the goals and objectives of TBIs. This will ensure that all catered startups are assisted in preparing them to be real entrepreneurs. All of these components will not be successful without getting Therefore, some of TBIs devised an income-generating project or mechanism to augment their financial needs. This finding appears in TBI 2 and TBI 3 where the use of space and facilities where rented by outsiders.

On the other hand the parameters under the process of implementation are promoting TBIs' services and facilities, protecting the products, innovations and inventions of start-ups, formulating policies and implementing rules and regulations, cascading best practices, alignment of TBI Vision, Mission and Goals to the Research, Extension and Innovation Thrust of the Institution and conduct of trainings, mentoring and coaching. In addition, continuous conduct of training, coaching, and mentoring will help startup companies to be independent. This finding is also similar to [3] where various services such as training and coaching are provided.

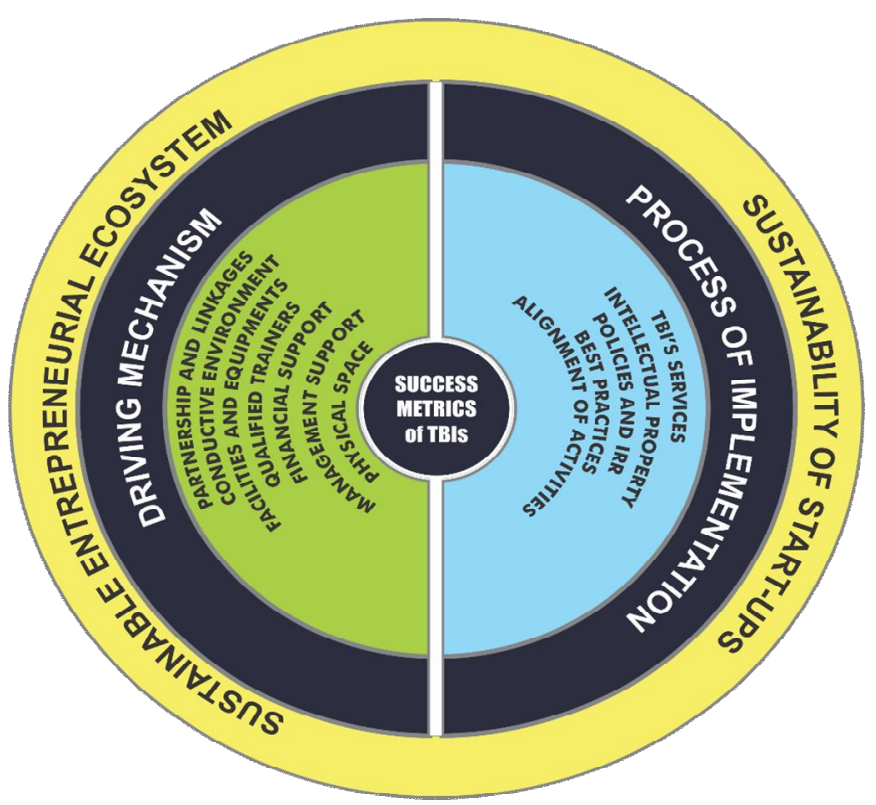

Figure 1: Success Metrics of TBIs in the Philippines

\section{ACKNOWLEDGEMENT}

The authors would like to acknowledge the funding given by the Commission on Higher Education (CHEd) as well as the Technological University of the Philippines to make this research viable and effective.

\section{REFERENCES}

1. Organisation for Economic Cooperation and Development (2019). Innovation. Retrieved from www.oecd.org/innovation/policyplatform/48136826.pdf financial opportunities or allotted funds for the operational use of TBIs. As mentioned in the previous discussion, many TBIs are still active and operational even if $90 \%$ of the startups fail, and the majority of TBIs are also startups too [9].

2. Mayuri, H. (n.d.) Business Incubators: Meaning, Definition, Services, Development and Types. Retrieved from: https://www.businessmanagementideas.com/startups/bu siness-incubators/business-incubators-meaning-definitio n-services-development-and-types/18192

3. Bergek, A. and Norrman, C. (2008). Incubator best practice: A framework. Technovation, (28), 1-2, 20-28.http://dx.doi.org/10.1016/j.technovation.2007.07. 008 https://doi.org/10.1016/j.technovation.2007.07.008

4. Arayat, MC. (2018, December 19). DOST, DICT, DTI partner to support startups. Retrieved from https://www.pna.gov.ph/articles/1057094

5. PWC (2017). Off to a great start: The Philippine Startup Ecosystem. 2017 Philippine Start Up Survey. Retrieved from https://www.pwc.com/ph/en/ceo-survey/2017/pwc-qbo-2 017-philippine-startup-survey.pdf

6. Vergara, R.A. (2018, July 26). The rising tech start-up scene in the Philippines. Business World

7. Busler, M. \& et. al. (2013). The Effect of Business Incubation in Developing Countries. European Journal of Business and Innovation Research. Vol. 1, No. 1, March 2013, pp.19-25. Retrieved from https://pdfs.semanticscholar.org/187c/9064f45938b2a07 f4538502f0b346c55ccf6.pdf?_ga=2.154755696.974872 179.1570622600-717811757.1565746542

8. Stefanovic, M., DevedzÃåic, G., \& Eric, M. (2008). Incubators in Developing Countries: Development Perspectives. International Journal for Quality Research (2) 3.

9. Singharam, M., \& Prathistha Jain (2017, December 28) . What Metrics Makes a Successful Incubator? https://www.entrepreneur.com/article/306697

10. Al-Mubaraki, H. M., \& Busler, M. (2013). Incubators Best Practices In Developed And Developing Countries: Qualitative Approaches. Asian Journal of Empirical Research, 3(7)2013: 895-910

11. Infodev (2010). Global Practice in Incubation Policy Development and Implementation . Retrieved from http://www.infodev.org/infodev-files/resource/InfodevD ocuments_834.pdf

12. Cluster (2020). Best Incubation Practices and activities aimed at supporting Creative and Digital Businesses: Connecting with Efficient Practices Across Europe. Retrieved from http://www.eciaplatform.eu/wp-content/uploads/2014/0 6/Best-Incubation-Practice_EBNReport_Cluster2020_FI NAL.pdf 
13. Pettigrew, A.M. (2014). The politics of organizational decision-making. Routledge, London, Tavistock. Perspective of the theory based on data: case report. Researchgate DOI 10.5205/reuol.7696-67533-1-SP-1.0908201520.

Retrieved December 14, 2018 from https://www.researchgate.net/publication/308796234_C oding_and_analyzing_data

14. Chong, C.H. \& Yeo, K. J. (2015). An overview of grounded theory design in educational research. Asian Social Science; Vol. 11, No. 12; 2015. Universiti Teknologi Malaysia, 81310 Skudai, Johor. ISSN 1911-2017.

https://doi.org/10.5539/ass.v11n12p258

15. Eberhardt, T., Soares de Lima, S.B., Soares, R., \& Kessler, M. (2016). Coding and analyzing data from the perspective of the theory based on data: case report. Researchgate DOI 10.5205/reuol.7696-67533-1-SP-1.0908201520.

Retrieved December 14, 2018 from https://www.researchgate.net/publication/308796234_C oding_and_analyzi ng_data.

16. Singh, S. \& Stephan, E. (2018). Selecting a grounded theory approach for nursing research. Global qualitative nursing research. SAGE Journal. https://doi.org/10.1177/2333393618799571

17. Skjott Linneberg, M. and Korsgaard, S. (2019). Coding qualitative data: a synthesis guiding the novice, Qualitative Research Journal, Vol. 19 No. 3, pp. 259-270. https://doi.org/10.1108/QRJ-12-2018-0012

18. Bruneel, J. , Ratinho, T., Clarysse, B., \& Groen, , A. (2013). The evolution of business incubators: Comparing demand and supply of business incubation services across different incubator generations. Technovation, 32 (2) (Feb 2012), pp. $110-121$

https://doi.org/10.1016/j.technovation.2011.11.003

19. Şehitoğlu, Y. \& Özdemir, O. (2013). The impact of business incubation on firm performance during post graduation period-Turkey example

20. Şehitoğlu, Y. \& Özdemir, O. (2013). The impact of business incubation on firm performance during post graduation period-Turkey example

21. Hackett, S.M., \& Dilts, D.M. (2004). A systematic review of business incubation research. The Journal of Technology Transfer, 29 (1) (Jan 2004), pp. 55-82 https://doi.org/10.1023/B:JOTT.0000011181.11952.0f

22. Merrifield, D.B. (1987). New business incubators. Journal of Business Venturing, 2, 277-284.

23. Bizzotto, C.E.N. (2003). The incubation process. Brazil: Gene Institute infoDev Incubator Support.

24. Yahya, N., Maidin, S.S. \& Soomro, A.B. (2019) Factors Influence Novice Programmers toward Test First Approach. International Journal of Advanced Trends in Computer Science and Engineering. Vol.8 No.4, 1283-1288

https://doi.org/10.30534/ijatcse/2019/39842019
25. Volkov D.V., Zubov M.V., Shatsky A.A. (2019). Formation of a Product Promotion Strategy Based on the Analysis of the Behavior of Network Users Through the Bruno de Finetti Paradox. International Journal of Advanced Trends in Computer Science and Engineering. Vol.8 No.4, 1421-1426 https://doi.org/10.30534/ijatcse/2019/60842019 